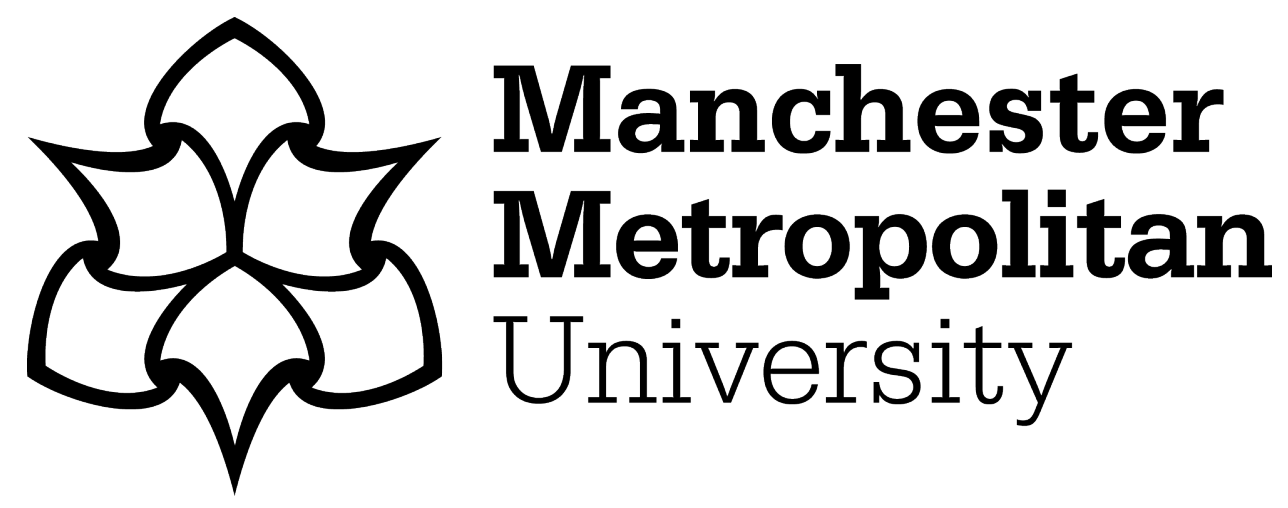

Fife, Kirsty ORCID logoORCID: https://orcid.org/0000-0002-8730-612X (2019) Not for you? Ethical implications of archiving zines. Punk \& Post Punk, 8 (2). pp. 227-242. ISSN 2044-1983

Downloaded from: https://e-space.mmu.ac.uk/628412/

Version: Accepted Version

Publisher: Intellect

DOI: https://doi.org/10.1386/punk.8.2.227_1

Please cite the published version 


\section{Not for you? Ethical implications of archiving zines}

\begin{abstract}
The archival value of zines (self-published pamphlets often produced by radical and marginalized communities) as historical records has been well documented in academic research. Red Chidgey refers to zines as 'sources of advocacy and empowerment for those who make them, an attempt to bear witness to their own lives'. As evidence of networks, cultures, linguistics and experiences of marginalized individuals and communities, zines often exist as the only representation of ephemeral and otherwise undocumented spaces, which makes them incredibly valuable as the primary source material.

Following the establishment of large zine collections at heritage spaces including the Women's Library, British Library, Wellcome Library and Tate, zines are now regularly collected and used in programming at heritage organizations. But what does it mean to archive and make use of zines - particularly those created by marginalized makers and communities - in an institutional heritage context? This article considers the ethical implications of archiving zine practice and cultures anti-institutional in its nature - in institutional spaces. Through a case study analysis of the community-led archive project Queer Zine Archive Project, I argue that, if zines are archived, it is imperative that archive workers are critically thinking about and incorporating the originating politics of zine culture into protocols for cataloguing, access, interpretation and use of these materials.
\end{abstract}

\section{KEYWORDS}

zines archives community heritage DIY punk music heritage music subcultures 


\section{INTRODUCTION}

The value of zines as historical objects has been well documented in scholarly research. Red Chidgey refers to zines as 'sources of advocacy and empowerment for those who make them, an attempt to bear witness to their own lives' (2006: 6). As evidence of networks, cultures, linguistics and experiences of marginalized individuals and communities, zines often exist as the only representation of ephemeral and otherwise undocumented spaces, which makes them incredibly valuable as a primary source material.

Following the establishment of large zine collections at heritage spaces including the Women's Library, British Library, Wellcome Library and Tate, zines are now regularly collected and used in programming at heritage organizations. Examples of this use include the facilitation of zine-making workshops in recent queer history programming at Tate Britain (2018), themed blog posts exploring intersections of zines and health by the Wellcome Library (Cook and Vigour 2017) and the announcement of a collection of zines relating to DIY sound and vision technologies at the National Science and Media Museum (Fife 2017). This, and other uses of zines by large heritage organizations, affords value to these objects within an institutional context. In relation to popular music heritage, Roberts and Cohen refer to this process as authorizing heritage:

Heritage can be officially authorised in a number of different ways. In the UK, for example, government bodies may categorise a building as ‘heritage' by including it on an official register or awarding it a commemorative plaque. This gives it a special status and may have moral and legal implications, increasing its value and importance and making it worth protecting and placing under formal protection.

The aforementioned programming and projects situate zines as historically and culturally significant in national heritage contexts. By bringing zines into a library, archive or museum, the creating communities are legitimized and authorized - and as such, community-led projects might be more able to access funding from heritage bodies (such as the Heritage Lottery Fund) to undertake other projects.

However, this also raises further questions when we consider the antiinstitutional and punk ethos that underpins zine-making practice. What does it mean to archive and use zines - often made by marginalized makers - in perpetuity? This article considers the ethical implications of archiving zine practice and cultures from marginalized communities. I begin by introducing zines as medium, practice, community and historical record. Following this I will summarize academic research on the interrelation between archives and societal power by postmodern archival theorists, and then go on to examine the impact of this power upon marginalized subjects, particularly (in the context of this article) zine-makers. I conclude by looking at the ways in which zine communities and other marginalized groups resist institutional power through the establishment of their own community-based archives using the case study of Queer Zine Archive Project (an online and community-led zine archive, hereafter referred to as QZAP). QZAP is selected as a case study because it is a community-led archive collecting zines made by a marginalized 
group (in this case, LGBTQ people) with both a physical and an online access function - thus making it an appropriate case through which to explore archival practice in this context. I will argue that, to preserve and facilitate access to zines as archival objects, it is important to incorporate the originating nonhierarchical and radical politics of DIY cultures and cultural production into archival practice.

\section{WHAT IS A ZINE?}

Zines,'non-commercial, small circulation publications which are produced and distributed by their creators' (Spencer 2005: 17), are commonly produced as a method of engagement with, and documentation of, countercultural movements and communities, and incorporate a variety of narrative and visual techniques that may include autobiographical writing, music and gig reviews, comics, illustration, collage, essays, political commentary, satire, life testimony and personal reflection. Zine-making practice began with science fiction fans in the early twentieth century, who produced 'fanzines' containing their own stories (in language informally referred to as 'fanspeak' within the culture), which were then traded and sold in the community (Spencer 2005: 82). These zines also contained extensive letter sections that enabled fans to communicate with each other through the medium and established networks for fans of the medium. Zines were later adopted by the Beat Generation in the 1950s, small presses in the mid-twentieth century and the punk community in the 1970s. A variety of communities have adopted the medium in the decades since, including football fans, third-wave feminists, queer people, anarchists and independent music fans.

Zines are often made by creators without any formal knowledge of publishing, and as such often possess a haphazard aesthetic that is colloquially referred to as 'cut and paste' in the community. Many creators will piece together zines by hand or through a basic grasp of desktop publishing, employing whatever few resources and skills that are available to them. This choice of aesthetic breaks down the boundaries that divide professional and amateur cultural production - as Stephen Duncombe writes, 'In an increasingly professionalized culture world, zine producers are decidedly amateur [...]. By their practice of eroding the lines between producer and consumer they challenge the dichotomy between active creator and passive spectator that characterises our culture and society' (1997: 133). A zine may more resemble a photocopied scrapbook rather than anything that we would otherwise consciously identify as a 'publication' - creators often appropriate, annotate and re-print copyrighted images, text and other copyrighted materials. This technique illustrates further some of the central politics of zine culture - disrespect for institutional rules, professional techniques and the re-writing of majority and mainstream culture to reflect subcultural and often subversive values.

DIY politics also factor into the ways in which zines are distributed. Zine creators are also often the people who manage the circulation and distribution of zines throughout the network. As Lymn writes, it is not only the zines themselves that are thus important, but 'how they exist within communities [...] [as] the people who write them (zinesters) are often the producers, distributors, collectors and consumers - roles in a zine's production and life cycle are not discrete' (Lymn 2013: 45). Zine creators thus not only control the content of their zines, but the people who have access to it. 
The way in which they are circulated and distributed ensures that the creator of the zine is still able to maintain some control over who has access to it it is thus hard to entirely consider them as publicly available and/or published documents. For example, a zine may have a total of 30 copies printed to distribute within a friendship group or local network, handed out individually by the zine maker. This method of distribution can make a zine markedly different to a published document such as a magazine or periodical, which is widely available from online retailers (for example) and that requires little or no interaction with the original creator(s). As Chidgey writes, these methods of circulation act

as a safety net giving zine writers a little more freedom to speak out about their personal lives, yet with the belief that their disclosures will remain relatively private to the general public and their immediate families. They are therefore written within a context based on an imagined community of truth-telling and the safe sharing of secrets and testimony.

(2006: 6)

These methods thus not only allow the creator to control who accesses their writing, but also provide the protection and anonymity needed to publish their testimonies.

\section{WHY ARE ZINES IMPORTANT AS HISTORICAL RECORDS?}

Alison Piepmeier (2009) has linked zines to other historical practices of selfpublication including scrapbook making, radical pamphleteering and community newsletters. Piepmeier writes that each of these genres of documents shares similar qualities; they are'created by hand, reproduced on a small scale, and shared in intimate settings' (2009: 39). Elizabeth Keenan and Lisa Darms (2013) connect zines to manuscript traditions because they share commonalities with personal archival documents including diaries and journals, which illustrate the way in which individual subjects have experienced events, time periods and passages of life. Sue McKemmish conceives of record-keeping as 'a "kind of witnessing"'. On a personal level, record keeping is a way of evidencing and memorialising our lives - our existence, our activities and experiences, our relationships with others, our identity, our "place" in the world' (1996: 175). Zines, often produced by one person, serve both as a representation of the way in which one person experienced an event or period of life; however, in turn they can also act as allegories for the experience of a wider group within society e.g. young women. As such, zines, as personal archives, represent both evidence of 'me', and what McKemmish refers to as 'an accessible part of [...] society's memory, its experiential knowledge and cultural identity - evidence of us' (1996: 175).

Zines are rarely created with the intention of becoming historical records; however, processes of documenting and memory making are central to many activist communities involved in zine creation and distribution. Zine-makers often engage with their exclusion from mainstream history and knowledge production practices, choosing to create and circulate their knowledge independently rather than interact with more formalized and academicized practices of history making. As a result, zines may be the only archival traces of marginalized communities. As Chidgey writes, 
zines are considered sources of advocacy and empowerment for those who make them, an attempt to bear witness to their own lives. This often occurs through a politicised historical consciousness (written in the vernacular) which seeks to privilege and explore the agency and actions of the non-elite; that is, to give testimony to the movements and complexity of their own lives.

(2006: 4)

Zines, thus whilst not intended to be historical records, offer rich amounts of materials for research into subcultures, communication and community networks and marginalized subjects who are otherwise not represented within archival holdings. In her article about zines made by young women, Kelly Wooten also draws attention to the historical merit of zines as evidence of networks and communities. As she writes,

Zines are artefacts of a particular moment in culture, where women and girls have access to the technology to publish their own works full of their opinions and ideas about the world in which they live. Their value lies not in the individual issues, but in the network and community that they represent as a whole.

(Wooten 2002: 25)

In addition to this, the zine network itself is of interest both academically and historically because of what it represents - the creation and maintenance of a community and space in which marginalized subjects are able to share experiences, strategies and resources. Whilst zine-makers may never meet, the processes of correspondence and interaction through letters, e-mails, fliers and commentary in zines allow participants in the community to 'instigate intimate, affectionate connections between their creators and readers, [creating] not just communities but embodied communities that are made possible by the materiality of the zine medium' (Piepmeier 2008: 214). This network is, thus, a lens through which it is possible to understand zines not as isolated objects created by one person or a single collective, but as a record representing the ways in which zine-makers communicate and relate to one another, and to society as a whole.

\section{ARCHIVES AND POWER}

The interrelation between archival institutions and societal power structures has been explored extensively in archival theory since the turn of the twenty-first century. Theorists including Joan Schwartz and Terry Cook (2002) and Eric Ketelaar (2005) have addressed 'the power reflected in the records and of the power of the records' (Ketelaar 2005: 184). Archives, often part of powerful institutions, hold the right to write and shape history, with archivists in control of what is kept, made available and how it is understood by users. Power has the capacity to oppress and marginalize minority groups, particularly when understood in conjunction with national and international histories of cultural appropriation. As Ieuan Hopkins writes, the very practices of acquiring, describing, arranging and exhibiting 'are inextricably linked to and implicated in past projects of colonialisation, with heritage institutions having been deployed in the establishment of dominance and control' (2008: 89). 
These practices of collecting and exhibiting become particularly politically charged when the collecting institution and/or archivist and the archived subject come from different positions of power within society. Hopkins writes about two ways in which materials relating to minority communities are (or are not) managed in heritage institutions. These are

Firstly, through 'erasure' or 'censorship', creating an 'absence' of evidence of different groups within the heritage. Secondly, where there is a presence within these institutions, through a misrepresentation or perception that the presence was 'ABOUT us rather than FOR us'.

(Hopkins 2008: 90)

This tension is omnipresent in heritage institutions, where calls to 'diversify' our heritage are often misinterpreted and lead to tokenistic or even exploitative approaches of marginalized subjects. As Flinn writes,

in reality the mainstream or formal archive sector does not contain and represent the voices of the non-elites, the grassroots, the marginalised. Or at least if it does, the archive rarely allows them to speak with their voice, through their own records.

It is not enough to merely include materials relating to marginalized subjects in our holdings without also further considering the way in which the very action of archiving can lead to further oppression and silencing of these groups.

The consequences of our failure to acknowledge the power imbalances between the archivist and the archived subject or community are drastic - as Joan Schwartz and Terry Cook write, 'when power is denied, overlooked, or unchallenged, it is misleading at best and dangerous at worst. Power recognized becomes power that can be questioned, made accountable, and opened to transparent dialogue and enriched understanding' (2002: 13) Whilst we may not be able to entirely undo the privilege that remains embedded within the sector as a whole, we can actively question our role to remain transparent and accountable to those whose records we manage.

\section{ZINE-MAKERS AS MARGINALIZED SUBJECTS}

In defining zines as a medium in the first section of this article, I also began to situate them as documentation created to engage with, subvert and critique the politics of mainstream knowledge and culture production. The zine maker is frequently positioned as a marginalized subject in scholarship. Duncombe believes that zines are most frequently made by 'losers' with 'loser ethics' that

stem from and appeal to those considered losers in a societal sense: people who are losers not because they are awkward and shy, but simply because they are denied or reject the wealth, power, and the prestige of those few who are the winners in society. 
Julie Chu also perceived zines as offering a place for the disenfranchised, writing that 'zine publishing [...] reclaims the importance of "small people" by articulating a place where those on the margins of power and, particularly, "outcasts" are central to the vitality of the space' (Chu 1997: 78).

Freedman sees zine-makers as 'people who have chosen to claim the margins' (Freedman 2012: 13). This process of choosing to claim the margins allows zine creators to find agency in this position, and to use it to document and record their methods of resistance. Writing about third-wave feminist activism as a whole, Lincona perceives this position as a 'third space' which 'reveals a differential consciousness' capable of engaging creative and coalitional forms of opposition to the limits of dichotomous (mis)representations. As a location, third space has the potential to be a space of shared understanding and meaning-making' (2005: 105). Subjects producing documentation at the fringes of society thus produce 'decolonized imaginary [...] that creatively resists and actively challenges the entrenched oppressions of structures and practices that have perpetuated dominant (mis)representations historically' (Lincona 2005: 105).

The zine-making community makes up a proportion of society that is structurally oppressed and excluded in practices of knowledge production, history making and preservation. The inclusion of zines within traditional archival institutions is, in itself, a radical act, given the types of voices and narratives present in their content, and the absence of these voices within pre-existing archival holdings. However, it is important to acknowledge that this process of collecting can in turn disempower the zine subject - through taking the materials out of their control, archivists can create what Julia Downes (writing in reference to riot grrrl culture) calls'a set of meanings that reaffirm cultural power in masculine hands' (Downes 2007: 12). Archival workflows including access protocols (including handling guidance, arrangement and description, digitization and interpretation through exhibition and display) all individually contribute to the way in which zines are understood and incorporated into history writing and other research. If these protocols do not align with the participatory context from which zines emerge, we risk further marginalizing the creators of these records.

\section{NEGOTIATING MARGINALIZATION: COMMUNITY-BASED ARCHIVES}

As a marginalized subject, engagement with history and knowledge production within an institutional context often involves negotiating the aforementioned processes of erasure or assimilation. The establishment of archives by marginalized communities indicates an awareness within these groups of both the importance of their histories and the need to retain control and ownership over the way it is used, who accesses it and how it is interpreted. Flinn defines community-led archive projects as incorporating the grassroots activities of documenting, recording and exploring community heritage in which community participation, control and ownership of the project is essential' (2007: 153).

Community-led archives are often established in a way that directly engages with the politics of history making and knowledge production. They are, in a parallel sense, another form of counter-cultural knowledge production - often created in response to feelings of invisibility and exclusion within more traditional or institutional archival organizations; they seek to establish spaces in which marginalized voices are recorded, documented, preserved and made accessible for those seeking them. As Stuart Hall says, 
'the activity of "archiving" is thus always a critical one, always a historically located one, always a contestatory one, since archives are in part constituted within the lines of force of cultural power and authority' (2008: 92).

The establishment of alternative spaces that allow communities to manage their own records without institutional support or management can be read as an act of resistance against these processes of assimilation and integration within problematic institutional structures. In addition to retaining ownership and custody of their records, this process of refusal also highlights the problems inherent in archival processes as a whole. As Barriault writes,

by removing themselves from the public archives arena, these specialized research centres have been able to challenge, to deconstruct, and to redefine what an archival institution should be in order to meet the needs of the $[\ldots]$ community they strive to document.

(2009: 226)

This process of deconstruction and redefinition acknowledges the complexity and dynamism of the archive as a conceptual, physical and political space. As Long et al. write in relation to archives of popular music, this 'promiscuous deployment of the title archive, the exploration of it as idea and its ontological status presents particular challenges to conventional practice for both archivist and user' $^{\prime}$ (2017: 63).

However, it is also important to acknowledge the issues and struggles that community-led archives can also face. Existing outside of an institutional context means less access to resources including funding, preservation quality storage, online catalogues and professionally qualified staff, less protection for heritage assets and a higher likelihood that an archive will need to move or relocate due to property development or other causes of loss of physical storage space. Community-led archival practice is a constant balancing act between navigating these precarious circumstances and limited resources, and the benefits of the autonomy of community-based contexts.

The following section of this article uses the case study of Queer Zine Archive Project, a community-led zine archive project that focuses on collecting zines made by LGBTQ people, to explore the ways in which marginalization, zine collecting and archival functions (such as digitization, cataloguing and access facilitation) intersect. The following is not intended to be a series of recommendations, but rather as a way to make visible and critically consider the impact of daily archival workflows on archives of and research into marginalized people (whether zine creators, users or archivists).

\section{CASE STUDY: QUEER ZINE ARCHIVE PROJECT}

Queer Zine Archive Project ('QZAP') is an online and physical archive project, created in 2003 by Chris Wilde and Milo Miller. The project holds a collection estimated during this interview to contain over 1200 zines. The website consists of a database of categorized and searchable archived zines. Each zine is viewable as an embedded document and is downloadable in PDF format. Topics range from queer punk music, queer culture, short stories, poetry, politics, to art, gender and sex. The physical archive is located in a flat in the basement of Miller and Wilde's home in Milwaukee, with physical access facilitated by Miller and Wilde. Researchers are able to stay in the apartment/archive during their visits. 
Radically different to most traditional archival organizations, Milo classes the project 'as a (dis)organization' - 'we are collectively run, and our members are a mix of punks, librarians, academics, burlesque dancers, and BMX bikers' (Carnegie Library of Pittsburgh Zine Collection 2012) Formed from within the radical queer community itself, QZAP's mission statement is as follows:

The mission of the Queer Zine Archive Project (QZAP) is to establish a 'living history' archive of past and present queer zines and to encourage current and emerging zine publishers to continue to create. In curating such a unique aspect of culture, we value a collectivist approach that respects the diversity of experiences that fall under the heading 'queer'. The primary function of QZAP is to provide a free on-line searchable database of the collection with links allowing users to download electronic copies of zines.

(Queer Zine Archive Project 2013:)

By enabling access to zines across a wider context than was perhaps initially intended by their creators (via digitization and an online catalogue), QZAP allows the zine community to engage not only with their peers in the specific geographic and generational context in which they are producing work, but also on international and cross-generational levels, facilitating new levels of discussion and discovery.

The motivation for establishing QZAP came from an awareness of the continuing relevance of queer zines to current activism projects, instead of the value of zines for future research. As Milo says,

When Chris and I met, we were doing organising work for Queerruption ${ }^{1}$ [...] questions kept coming up about what is queer, or what are we talking about, or how do we provide safe spaces? [...] And because Chris and I had both been making zines and collecting them, we kept looking at each other and looking at some of the other folks in the room and saying 'this is in a zine somewhere, I know that somebody wrote this!'

(Miller and Wilde 2013)

This comment illustrates both the impetus behind the founding of QZAP and a wider issue about the lack of historical documentation within activist communities, leading to what Sarah Dyer calls 'the discontinuity of history',

that so often happens when material is ephemeral or marginal [...] So much information and thinking is lost, and then so much information has to be rediscovered again and again, wasting time and energy that could be used to move forward.

The lack of preservation of materials often leads activist communities to have to 'reinvent the wheel' when issues recur and problems need solving. In this sense, QZAP functions as much for current generations as for future researchers. As Sarah Baker and Alison Huber write, projects such as this

are not solely about the creation of storerooms 'for the future', but are equally as important for the memory practices of 'the present'; by this we mean that those involved in the DIY enterprise are engaged in the
1. Queeruption is an annual international queercore festival and gathering started in 1998 where queer people can exchange information, network organize, inspire and get inspired, self-represent and challenge mainstream society with do-ityourself (DIY) ideas and ethics. Shows featuring queer punk bands, performance artists and other entertainment are put on at night, while workshops and demonstrations take place during the daytime. Queeruption generally takes place in a different city in a different country every year. 
process of materialising their own experience and expertise through the collection, declaring and naming its importance.

QZAP is both housed in and run by the queer community itself, and as such the managing collective are able to preserve zines without engaging with formal institutional archives. This builds trust and enables empowerment in a way that is harder to achieve within the context of a formal institution. As Chris says,

who can we trust to archive our stories and our zines and our history? [...] We're entering the historical phase of queer zine legacy and we have this amazing opportunity to be there as part of the preservation as people who were part of the original movement, who were the original creators of zines. That's also something - I mean we take it for granted, but when we see it reflected back to us, we understand that a lot of historical movements are usually documented or preserved by folks who have no connection to it $[. .$.$] it definitely puts us in a very different posi-$ tion $[. .$.$] having been content creators and now preserving the material.$ $[\ldots]$ that's the trust that it engenders and what we really see as a role for QZAP.

(Miller and Wilde 2013)

Trust is a concept discussed frequently in relationship to official and governmental records, particularly in relation to ensuring the authenticity and trustworthiness of our archival holdings. As professionals, archivists invest in 'the twin pillars of the archivist as "trusted custodian" and archival institutions as "trusted repositories" [and their capacity to] combine to ensure "trustworthy records"' (Flinn and Shepherd 2011: 171). However, less attention is paid to the importance of trust in relationships between donors, users and archives themselves - particularly in relationship to marginalized communities. Queer history is, by its very nature, a traumatic research area, and those seeking the records that exist in archival holdings (community-led or more traditional institutions) may seek more private discovery experiences than more traditional users. In turn, those depositing materials may wish to specify different access protocols from those expected of traditional archival records. As a result, a 'trusted' custodian or repository in this context may well be different to what archival theorists have traditionally believed. Trust can instead be fostered through the capacity to care for it in a way in which centres the relevant community, rather than postgraduate education and qualification. This 'represents a tremendous challenge to the basic assumptions of archival fixity and materiality' (Burton 2005: 2) and indeed our very conception of what trust is in relation to archival records.

The need for trust and ongoing suspicion around the use and management of materials made by marginalized and subcultural communities is further heightened when the materials in question are also personal, controversial and potentially dangerous for the producers and the users of a collection. QZAP's collection consists of intensely personal materials, and it is also, through its commitment to online access, heavily driven to provide wider access via digitization. The juxtaposition of intensely personal, sensitive and/ or controversial content and online access to materials means that issues around consent have an extra dimension for them. In Miller's own words, 
'we recognise that the material in our collection is potentially dangerous, and it threatens the status quo and it talks about things that you might not want your mum to know that you're reading about or whatever' (Miller and Wilde 2013).

With both a physical and an online dimension to QZAP, different levels of consent are required depending on the mode of access that a user chooses. Some donations are kept restricted and unavailable for online access 'certainly we have stuff in the archive that people have sent to us and they've asked us to preserve it and hold onto it but they've also asked that it not be made available online' (Miller and Wilde 2013). The archive ensured that trust was retained through the acquisition process - first, donors signed consent forms clarifying terms of access (online/physical/closure for a period of time) upon deposit, and second, where collectors had donated copies of other peoples' zines, effort was made to contact the original creators and obtain permission. As Milo says,

There definitely is a consent issue around putting things online, and we try our best to do due diligence, meaning that if there's any sort of contact information or if we know somebody who knows somebody who might know that person, we try to ask permission before putting things online $[\ldots]$ we tend to err on the side of it's okay unless somebody tells us otherwise, but that's only if we cannot get a hold of people, and usually, um, $y^{\prime}$ know in some instances the creators are deceased or their friends that would know them say yes it's fine that you could do this, um, we very rarely, a couple of times, but not often, had people request that we either change information related to the digital zine or that we take things down but we try very, very hard to ask first.

(Miller and Wilde 2013)

The archive's procedures around consent have evolved over the decade that it has been in operation. As Chris says, 'for the longest time we just sort of collected, and thought, and sort of felt oh we'll get to it in a few months and then we'll ask, and now I think we're having those conversations right away' (Miller and Wilde 2013). The practice of immediately asking 'when people donate things to us if we have their permission to put things online' (Miller and Wilde 2013) means that the archive is now able to negotiate the terms of deposit directly with donors at the point of donation. This is not always possible - particularly with collections donated by collectors or containing historical materials made by creators who are now uncontactable; however, in these cases, clear communication about the capacity to remove zines or alter catalogue on the website enables the archive to remain access focused without infringing upon the privacy of those who are uncontactable. This arrangement was not ideal; however, it represented the best balance between the need for access by the community and the right to privacy for creators.

Trust factors into both the donor-archive relationship and the user-archive relationship. As an online archive, QZAP are in the position of being able to choose whether to monitor their online user visits. However, as Milo says, 'for a number of reasons we have never kept track of who visits the website, and so we don't totally know what our reach is in the digital world' (Miller and Wilde 2013). Chris elaborates, saying that 'we also strongly believe in the freedom to seek information, so we don't necessarily want to know what it is that people are looking for in general [...] it's sort of a principle of open stacks 
(Miller and Wilde 2013). This policy is a logical extension of the archive's awareness of the intensely personal and sometimes controversial nature of queer zines. In choosing not to monitor their online users, QZAP enable users to have an entirely private discovery experience, something that is not possible with physical access. This focus on private discovery through browsing enables the user to engage with the archive as "an archive of feelings", an exploration of cultural texts as repositories of feelings and emotions, which are encoded not only in the content of the texts themselves but in the practices that surround their production and reception' (Cvetkovich 2003: 3). The importance of privacy is also discussed by Keenan and Darms in relation to the archival traces of riot grrrl culture (which include a substantial amount of zines). In relation to this they write

The relationship of these two 'publics' - the public from whom these personal papers are drawn and the public who uses the collection raises questions about access, privacy, and privilege, as well as the protected but complex nature of the safe space that Riot Grrrl sought to establish and that the archive mirrors.

(Keenan and Darms 2013: 57)

The right to privacy is, in many cases, the right to a safe(r) space/safety in queer and feminist cultures. When the documentary materials of these cultures become archives and primary sources for research, it is again imperative to think about how this need for privacy and safety intersects with the desire for access to and publication or digitization of materials.

In its very conception, as a predominantly online project handling materials of a highly sensitive nature both to creators and readers alike, QZAP's collection contains objects to which it is challenging to facilitate access. As a community-led project born out of the queer zine community itself, the archive is able to preserve and facilitate access to zines in a way that, to some extent, keeps them within their original creating context. However, the facilitation of international online access means that, whilst the zines themselves are kept within the creating community, the reach of the documents is vastly larger than the creators often intend. This juxtaposition of personal, sensitive materials, online access and long-term preservation means that good consent and ethics have to form a central part of all parts of the archival process. This is particularly important in the context of an archive of queer zines by marginalized makers, which is in many ways reliant on creators sharing intimate and personal records with a wide and unknown user base. As Keenan and Darms write, this collaborative and community-led practice is reliant on the willingness of these donors to make themselves vulnerable - to make their private lives public - [to allow] this evolving history to be preserved' (2013: 74).

\section{CONCLUSION}

This article has sought to consider the ethical implications of and methods for archiving zines. By seeking to collect and preserve zines, we are documenting history in the voices of those who are otherwise not present in mainstream media, knowledge production or culture. As records, they fill in the gaps between history as recorded by institutions and as experienced by individuals. 
Zines sit awkwardly between public documents (such as pamphlets or newsletters) and private documents (such as letters or diaries). This negotiation 'of the specific and the generalisable - their sometimes messy careening between the local and the global, the personal and the political' (Piepmeier 2009: 10), typifies them as a genre, and is part of what makes them interesting and radical as documents. It also means that they do not easily fit within categories of records. As a result, it is important that the archivists collecting and preserving them maintain an understanding of this somewhat precarious, messy positioning and how it relates to traditional archival protocols.

The right to claim control over one's voice and the ways in which it is circulated and understood is at the very centre of zine-making culture. Zine creators often produce their zines in response to feelings of alienation and marginalization by mainstream, hierarchical models of cultural and knowledge production. This 'desire for self-determination indicates a desire to act politically and to assign significance to one's own life and the lives within one's community' (DiVeglia 2012: 78). In seeking to archive these materials, it is thus imperative that there is (as a minimum) some community involvement, dialogue and participation in archival workflows, extending the politics of self-determination beyond the documents themselves to their preservation within archives. This need for communication, participation and collaboration has clear parallels with sector-wide calls for a more ethically engaged approach to collecting activities in marginalized communities (Dunbar 2006; Keenan and Darms 2013; Hopkins 2008; Caswell et al. 2017; Flinn 2011). The dialogue around consent, communication use, access and circulation also should not stop once materials are deposited - it is an ongoing process that should continually inform the preservation and future use of these materials for learning and teaching, history writing, research and all forms of knowledge production.

\section{REFERENCES}

Baker, S. and Huber, A. (2015), 'Saving "rubbish": Preserving popular music's material culture in amateur archives and museums', in S. Cohen, R. Knifton, M. Leonard and L. Roberts (eds), Sites of Popular Music Heritage: Memories, Histories, Places, Routledge Studies in Popular Music, London and New York: Routledge, pp. 112-24.

Barriault, M. (2009), 'Hard to dismiss: The archival value of gay male erotica and pornography', Archivaria, 68, pp. 219-46.

Burton, A. (ed.) (2005), 'Introduction: Archive fever, archive stories', Archive Stories: Facts, Fictions, and the Writing of History, Durham, NC: Duke University Press, pp. 1-24.

Carnegie Library of Pittsburgh (2012), 'Interviews with great folks \#3: Milo from QZAP', CLP Zines, 17 July, http://clpzines.wordpress.com/2012/ 07/17/interviews-with-great-folks-3-milo-from-qzap/. Accessed 13 July 2013

Caswell, M., Migoni, A. A., Geraci, N. and Cifor, M. (2017), '“to be able to imagine otherwise": Community archives and the importance of representation', Archives and Records, 38, pp. 5-26.

Chidgey, R. (2006), 'The resisting subject: Per-zines as life story data', University of Sussex Journal of Contemporary History, 10, pp. 1-13. 
(2013), 'Reassess your weapons: The making of feminist memory in young women's zines', Women's History Review, 22:4, pp. 1-15.

Chu, J. (1997), 'Navigating the media environment: How youth claim a place through zines', Social Justice, 24:3, pp. 71-85.

Cook, N. andVigour, L. (2017), 'Rag mags and monthly issues: Five period zines to stop you seeing red', Wellcome Collection, 1 November, https://wellcomecollection.org/articles/We70GR4AAHEelso2. Accessed 26 December 2018

Cvetkovich, A. (2003), An Archive of Feelings: Trauma, Sexuality, and Lesbian Public Cultures, Durham, NC: Duke University Press.

DiVeglia, A. L. (2012), 'Accessibility, accountability, and activism: Models for LGBT archives', in L. Bly and K. Wooten (eds), Make Your Own History: Documenting Feminist and Queer Activism in the 21st Century, Los Angeles: Litwin, pp. 69-89.

Downes, J. (2007), 'Riot Grrrl: The legacy and contemporary landscape of DIY feminist cultural activism', in M. Modem (ed.), Riot Grrrl: Revolution Grrrl Style Now!, London: Black Dog Publishing, pp. 12-52.

— (2010), 'DIY queer feminist (sub)cultural resistance in the UK', Ph.D. thesis, Leeds: University of Leeds.

Dunbar, A. (2006), 'Introducing critical race theory to archival discourse: Getting the conversation started', Archival Science, 6:1, pp. 109-29.

Duncombe, S. (1997), Notes from Underground: Zines and the Politics of Alternative Culture, Portland: Microcosm Publishing.

Eichhorn, K. (2010a), 'D.I.Y. collectors, archiving scholars, and activist librarians: legitimizing feminist knowledge and cultural production since 1990', Women's Studies: An Inter-Disciplinary Journal, 39:6, pp. 622-46.

- (2010b), 'Sites unseen: Ethnographic research in a textual community', International Journal of Qualitative Studies in Education, 14:4, pp. 565-78.

- (2012), 'Archiving the movement: The Riot Grrrl Collection at Fales Library and special collections', in L. Bly and K. Wooten (eds), Make Your Own History: Documenting Feminist and Queer Activism in the 21st Century, Los Angeles: Litwin, pp. 23-39.

Fife, K. (2017), 'Insight: Collecting zines at the National Science and Media Museum', 9 August, https://blog.scienceandmediamuseum.org.uk/insightcollecting-zines-at-the-national-science-and-media-museum/. Accessed 26 December 2018.

Flinn, A. (2007), 'Community histories, community archives: Some opportunities and challenges', Journal of the Society of Archivists, 28:2, pp. 151-76. (2011), 'Archival activism: Independent and community-led archives, radical public history and the heritage professions', InterActions: UCLA Journal of Education and Information Studies, 7:2: pp. 1-21.

Flinn, A. and Shepherd, E. (2011), 'Questions of trust (and distrust)', Archival Science, 11: pp. 169-74.

Freedman, J. (2012), 'Self-publication with Riot Grrrl ideals: Zines =/= vanity press publications', in L. Bly and K. Wooten (eds), Make Your Own History: Documenting Feminist and Queer Activism in the 21st Century, Los Angeles: Litwin, pp. 13-23,

Hall, S. (2008), 'Constituting an archive', Third Text, 15:54, pp. 89-92.

Hopkins, I. (2008), 'Places from which to speak', Journal of the Society of Archivists, 29:1, pp. 83-109.

Keenan, E. K. and Darms, L. (2013), 'Safe space: The Riot Grrrl Collection', Archivaria, 76, pp. 55-74. 
Ketelaar, E. (2005), 'Recordkeeping and societal power', in F. Upward, M. Piggott, B. Reed and S. McKemmish (eds), Archives: Recordkeeping in Society, New South Wales: Charles Stuart University, pp. 277-98.

Lincona, A. C. (2005), '(B)orderlands' rhetorics and representations: The transformative potential of feminist third-space scholarship and zines', NWSA Journal, 17:2, pp. 104-29.

Long, P., Baker, S., Istvandity, L. and Collins, J. (2017), 'A labour of love: The affective archives of popular music culture', Archives \& Records, 38, pp. 61-79.

Lymn, J. (2013), 'The zine anthology as archive: Archival genres and practices', Archives and Manuscripts, 41:1, pp. 44-57.

McKemmish, S. (1996), 'Evidence of me...', Archives and Manuscripts, 24:1, pp. $28-45$.

Miller, M. and Wilde, C. (2013), interviewed by Kirsty Fife, London, 4 July.

Piepmeier, A. (2008), 'Why zines matter: Materiality and the creation of embodied community', American Periodicals: A Journal of History, Criticism, and Bibliography, 18:2, pp. 213-38.

_ (2009), Girl Zines: Making Media, Doing Feminism, New York and London: New York University Press.

Queer Zine Archive Project (2019), 'Home', QZAP, http://www.qzap.org. Accessed 30 May 2019.

Roberts, L. and Cohen, S. (2014), 'Unauthorising popular music heritage: Outline of a critical framework', International Journal of Heritage Studies, 20: 3, pp. 241-61.

Schwartz, J. and Cook, T. (2002), 'Archives, records and power: The making of modern memory', Archival Science, 2:1-2, pp. 1-19.

Shilton, K. and Ramesh, S. (2007), 'Participatory appraisal and arrangement for multicultural archival collections', Archivaria, 63, pp. 87-101.

Sinor, J. (2003), 'Another form of crying: Girl zines as life writing', Prose Studies: History, Theory, Criticism, 26:1\&2, pp. 240-64.

Spencer, A. (2005), DIY: The Rise of Lo-Fi Culture, London: Marion Boyers.

Tate Britain (2018), 'Tate Britain workshop: Queer zine-making workshop', Tate Britain, https://www.tate.org.uk/whats-on/tate-britain/workshop/ queer-zine-making-workshop. Accessed 26 December 2018.

Wooten, K. (2002), 'Women's zines in the Sarah Dyer Zine Collection', master's thesis, Chapel Hill, NC: School of Information and Library Science, University of North Carolina.

\section{SUGGESTED CITATION}

Fife, K. (2019), 'Not for you? Ethical implications of archiving zines', Punk $\mathcal{E}$ Post-Punk, 8:2, pp. 227-42, doi: 10.1386/punk.8.2.227_1

\section{CONTRIBUTOR DETAILS}

Kirsty Fife is a Ph.D. student in the Department of Information Studies at UCL. Her Ph.D. research is about methods for documenting and archiving current UK-based DIY music spaces. Prior to commencing her research, she worked as an archivist for organizations including the UK Parliamentary Archives and the National and Science and Media Museum. Outside of her academic and professional roles, she is also an active DIY cultural organizer, musician and zine-maker. 
Contact: Department of Information Studies, UCL, Gower Street, WC1E 6BT, London, UK.

E-mail: k.fife.12@ucl.ac.uk

Kirsty Fife has asserted her right under the Copyright, Designs and Patents Act, 1988, to be identified as the author of this work in the format that was submitted to Intellect Ltd. 